Canadian Journal of Applied Linguistics

Revue canadienne de linguistique appliquée

\title{
Principals' Beliefs About Language Learning and Inclusion of English Language Learners in Canadian Elementary French Immersion Programs
}

\section{Callie Mady and Mimi Masson}

Volume 21, Number 1, 2018

URI: https://id.erudit.org/iderudit/1050811ar

DOI: https://doi.org/10.7202/1050811ar

See table of contents

\section{Publisher(s)}

University of New Brunswick

ISSN

1920-1818 (digital)

Explore this journal

Cite this article

Mady, C. \& Masson, M. (2018). Principals' Beliefs About Language Learning and Inclusion of English Language Learners in Canadian Elementary French Immersion Programs. Canadian Journal of Applied Linguistics / Revue canadienne de linguistique appliquée, 21(1), 71-93.

https://doi.org/10.7202/1050811ar

\section{Article abstract}

Gatekeepers' language ideologies and beliefs about language learning determine how learners experience French as a second language programs, in particular, their access to, and success and inclusion in, the French immersion (FI) program. In this article, we explore how FI principals understand language learning and the inclusion of English language learners (ELLS) and how these perspectives shape school policy in FI programs. The study took place in a large urban school board in southern Ontario with student population consisting of $50 \%$ ELLs. After conducting a questionnaire with principals across the school board, we interviewed a subgroup of principals gathering quantitative and qualitative data. In addition, we consulted the board's website and documentation provided to parents regarding enrolling their children in FI. The study highlights convergence or divergence from principals' beliefs in relation to board policy about access and inclusion to the FI program. Through critical discourse analysis, data revealed that principals have contradictory beliefs about language learning, and at times principals struggle to reconcile these beliefs with official board policy. While FI principals are mostly positive about including ELLs in FI, to provide equal access to the program, they would benefit from (a) moving away from a definition of bilingualism as equalingualism and (b) expanding and developing the meaning of inclusivity beyond physical presence to adapt the FI space for greater inclusion of ELLs.
Copyright (c) Callie Mady, Mimi Masson, 2018

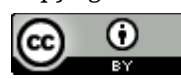

This document is protected by copyright law. Use of the services of Érudit (including reproduction) is subject to its terms and conditions, which can be viewed online.

https://apropos.erudit.org/en/users/policy-on-use/ 


\title{
Principals' Beliefs About Language Learning and Inclusion of English Language Learners in Canadian Elementary French Immersion Programs
}

\author{
Callie Mady \\ Nipissing University \\ Mimi Masson \\ OISE, University of Toronto
}

\begin{abstract}
Gatekeepers' language ideologies and beliefs about language learning determine how learners experience French as a second language programs, in particular, their access to, and success and inclusion in, the French immersion (FI) program. In this article, we explore how FI principals understand language learning and the inclusion of English language learners (ELLs) and how these perspectives shape school policy in FI programs. The study took place in a large urban school board in southern Ontario with student population consisting of $50 \%$ ELLs. After conducting a questionnaire with principals across the school board, we interviewed a subgroup of principals gathering quantitative and qualitative data. In addition, we consulted the board's website and documentation provided to parents regarding enrolling their children in FI. The study highlights convergence or divergence from principals' beliefs in relation to board policy about access and inclusion to the FI program. Through critical discourse analysis, data revealed that principals have contradictory beliefs about language learning, and at times principals struggle to reconcile these beliefs with official board policy. While FI principals are mostly positive about including ELLs in FI, to provide equal access to the program, they would benefit from (a) moving away from a definition of bilingualism as equalingualism and (b) expanding and developing the meaning of inclusivity beyond physical presence to adapt the FI space for greater inclusion of ELLs.
\end{abstract}

\section{Résumé}

Les idéologies et les opinions des gardiens de l'accès au français langue seconde déterminent la façon dont les apprenants vivent leurs expériences dans les programmes de français langue seconde, y compris leur accès au programme d'immersion française, leur réussite scolaire et leur inclusion dans le programme. Dans cet article, nous examinons comment les directeurs d'école d'immersion française voient l'apprentissage d'une langue et l'inclusion des apprenants d'anglais langue seconde et comment leurs perspectives influencent la politique de langue dans le programme d'immersion française dans leurs écoles. L'étude s'est déroulée dans un grand conseil scolaire urbain dans le sud de l'Ontario où $50 \%$ des élèves sont des apprenants d'anglais langue seconde. Après avoir effectué des questionnaires auprès des directeurs d'école du conseil scolaire, nous avons fait des entrevues avec un sous-groupe de directeurs d'école pour récolter des données quantitatives et qualitatives. De plus, nous avons consulté le site Web du conseil scolaire et ainsi que les documents qui sont fournis aux parents qui veulent inscrire leurs enfants dans le programme d'immersion française. Par le 
biais d'une analyse de discours critique, les données ont révélé que les directeurs d'école avaient des opinions contradictoires au sujet de l'apprentissage des langues, et dans certains cas, les directeurs d'école avaient de la difficulté à concilier leurs opinions et la politique officielle du conseil scolaire. Bien que les directeurs d'école soient généralement positifs au sujet de l'inclusion des apprenants d'anglais langue seconde dans le programme d'immersion française, pour assurer un accès égalitaire au programme, les directeurs d'école pourraient bénéficier $\mathrm{du}$ fait (a) de se distancer d'une définition du bilinguisme comme « équilinguisme » et (b) d'étendre et de développer la définition du concept de l'inclusion au-delà de la présence physique dans la salle de classe pour y intégrer les principes d'inclusion de façon plus approfondie et créer un espace favorable au développement linguistique des apprenants d'anglais langue seconde dans le programme d'immersion française. 


\section{Principals' Beliefs About Language Learning and Inclusion of English Language Learners in Canadian Elementary French Immersion Programs}

Schools in urban areas of Canada have a growing immigrant student population (Statistics Canada, 2014), referred to as English language learners (ELLs) in this paper. These students speak languages other than English at home and their families seek to benefit from adding English and French to their linguistic repertoires. Such changes in the school population suggest an increasing need for a multilingual approach toward language learning in Canada. And yet, ideologies rooted in monolingual perspectives (Grosjean, 1982; Pavlenko, 2006) on languages persist among some educational gatekeepers. Their beliefs about language impact how learners experience French as a second language (FSL) programs, ${ }^{1}$ in particular their access to, and success and inclusion in, the French immersion (FI) program. In this article, we explore FI principals' ideologies about language learning and the inclusion of ELLs, and how these perspectives shape school policy in FI programs.

\section{Background}

\section{The French Immersion (FI) Context in Canada}

In the 1960s, FI emerged to help English-speaking children learn French, marking a growing interest in Canadian French-English bilingualism. In 1969, the Official Languages Act granted equal and official status to both languages; however, official language bilingualism was not viewed positively by all. The Association of Catholic Principals of Montreal (1969, cited in Lambert \& Tucker, 1972) stated, "we are of the opinion that the average child cannot cope with two languages of instruction and to try to do so leads to insecurity, language interference, and academic retardation" (p. 5). Stern et al. (1976) reported that sceptical educators and psychologists of the time believed that FI could be "disorienting, emotionally damaging, and intellectually stultifying" with "negative psychological and cognitive effects" (p. 17). Stern et al. revealed, however, no adverse psychological effects, concluding that FI programs were highly effective for learning French. Despite the resistance to bilingual education, various studies have revealed the linguistic, academic, and cognitive benefits of FI. In his review, Lazaruk (2007) found high levels of French proficiency at no cost to academic success, heightened mental flexibility and creative thinking skills, enhanced metalinguistic awareness, and greater communicative sensitivity. Research has also shown that students in FI have improved metalinguistic abilities (Hermanto, Moreno, \& Bialystok, 2012) and metacognition (Turnbull, Hart, \& Lapkin, 2003), and develop second language skills and content knowledge in a given subject matter with no negative effect on first language literacy and numeracy (Turnbull, Cormier, \& Bourque, 2011).

Such positive results have met with scrutiny (e.g., Willms, 2008) given the practice of discouraging certain students, such as ELLs (Mady, 2007), from joining or remaining in the program (Mady \& Arnett, 2009; Wise, 2011). Wall (2010) outlined a set of pervasive myths about the FI program stemming from its hypothesized inability to adapt to newer, diverse populations of students. This student selection persists despite studies showing that ELLs perform as well as, if not better than, their monolingual English counterparts in FI (Mady, 2014b). 


\section{Research on English Language Learners (ELLs) in French Immersion (FI)}

Bilingualism in Canada's two official languages can be a social and/or political advantage (Heller, 2003). Naturally, some recently-arrived immigrants have sought out the same benefits for their children. Ethnographic research into multilingual learners' identities has revealed that immigrant parents choose FI with the goal of adding English and French to their children's linguistic repertoires (e.g., Dagenais, 2003; Dagenais \& Berron, 2001; Dagenais \& Moore, 2008). Yet, the influx of multilingual children presents challenges for FI educators and administrators. Mady (2012a) reported that $50 \%$ of her ELL participants have been actively discouraged from entering FSL programs. In another study exploring the voices of immigrant adults, findings indicated that these adults were also challenged when trying to access FI for their children (Mady, 2012b). Once granted access, ELLs may not present success in the manner that might be expected. For instance, in Dagenais, Day, and Toohey's (2006) study, one multilingual student was deemed unsuccessful by her FI teacher for not demonstrating participation normatively (e.g., volunteering to respond to questions orally) despite showing successful alternative ways of participating; the teacher expressed the view that the student should probably transfer out of FI. The rapidly changing linguistic ecologies in the FI classroom bring to light the issue of equitable access to the FI program and professional development to address ELLs' needs.

\section{Gatekeepers of French Immersion (FI) Programs}

How gatekeepers in FI schools make sense of the new linguistic ecology of their school is important to student success and implementing policy equitably. Principals play a key role in setting the tone for the school; however, there is little research looking into principals' perceptions of inclusion in FI programs. Studies seeking insight into principals' perspectives are situated within the broader scope of FSL programs. In her questionnaires and interviews with principals, Calman (1988) found that principals left decisions about the FSL program to the FSL teachers. Turnbull (2008) found that principals who have taught FSL in the past value it significantly more than those who have not. Roy (2012) echoed these findings in her study showing that gatekeepers' own understanding and positioning toward language and social identities matter in shaping the discourses that run in the school. In their recent study, Milley and Arnott (2016) looked into how gatekeepers perceived the principal's role in FSL and found that only three of the eight teacher-principal pairings interviewed revealed converging positive instructional leadership practices.

There is limited information on principals' perspectives of ELLs in FSL programs. In focus groups and individual interviews involving 403 participants, less than half of FSL principals (46\%) believed that ELLs should take part in learning French (Turnbull, 2008). The rest either believed ELLs should not be in FSL programs $(25 \%)$ or they were not sure what to believe (29\%). Mady (2006) also interviewed principals of schools offering FSL programs and discovered that none of the principals provided opportunities for all ELLs to study FSL as required by the curriculum. In the same study, $54 \%$ of principals reported that ELLs in their schools did not take French courses, while the rest reported that ELLs sometimes did. Principals cited age of arrival, need to focus on English, and lack of special French courses designed for ELLs as influencing factors. 
Beliefs based on the "common sense" principle. Gatekeepers' perceptions of language learning inform their practices involving ELLs in FI programs. Research has confirmed that gatekeepers often base their decisions on their personal beliefs, which are not always founded on language education theories or empirical evidence (e.g., Arnett, Mady, \& Muilenburg, 2014; Arnett \& Turnbull, 2008). Studies investigating gatekeepers' beliefs about ELLs in FI programs have focused on teachers' perspectives. Bourgoin (2016) found that some teachers' beliefs about ELLs limit these students' access to FI programs. For instance, some teachers believed that learning French while negotiating English and another language is too demanding or that learning French requires certain behavioural expectations. These "common sense principles" (Cummins, 2007) are rooted in a monolingual understanding of languages as separate entities that may interfere with each other. In addition, "monolingual bias" creates a hierarchy among languages. As Dagenais (2013) pointed out, "many Canadian schools continue to privilege the language(s) of instruction [i.e., English and French] to the exclusion of other languages" (p. 293).

Beliefs informed by monolingual bias translate to classroom practice. Mady (2014a) reported that FI teachers, in cases where they do they draw on additional languages, only make reference to English, even when they share additional languages with students. These practices emerge in the classroom, despite the fact that keeping multilingual students' linguistic resources artificially segregated does not always help with their language learning (e.g., Antón \& DiCamilla, 1998; Swain \& Lapkin, 2000; Turnbull, 2001) and that crosslinguistic transfer may actually be helpful to learners (Swain \& Lapkin, 2002; Thomas \& Mady, 2014; Tipurita \& Jean, 2014).

Beliefs based in the conception of the "ideal language learner." When gatekeepers make decisions about the suitability of one learner over another, these decisions might be based on prior understanding of what is a "good language learner." Bourgoin (2016) examined Grade 2 English teachers' perspectives on the inclusion of ELLs in the FI program. She found that gatekeeping teachers have strong, unsubstantiated beliefs about what students are suitable for the FI program: those with strong academic skills, who are hardworking, motivated, and quick learners. These assumptions, associated with the ideal learner, have persisted from decades past. In 1975, Rubin defined a "good learner" as someone who is a "willing and accurate guesser" (p. 45), has a "strong drive to communicate" (p. 46), is "often not inhibited" (p. 47), and is "prepared to attend to form" (p. 47). Stern (1975) identified strategies used by good language learners for whom the "ideal end point of the learning process is native-like competence" (p. 20). Anchoring to a monolingual view of what constitutes successful learning (e.g., attaining "native-like" proficiency) positions those who cannot attain this goal as "unsuccessful learners" and deficient (e.g., Wenden, 1985). In one study, ELLs outperformed their Canadian-born or monolingual peers (Mady, 2015) on tests of French achievement, highlighting that still today "these attitudes [stemming from the monolingual perspective] distort and devalue many aspects of multilingual behavior" (Sridhar, 1996, p. 59). As we learn more about the diversity of learners, questions of equitable access and the way that inclusivity is practiced in FI emerge (Mady \& Black, 2012). The changing linguistic ecology of the language classrooms in Canada takes on the additional issue of social justice, specifically with regard to taking multilingual learners' educational needs into consideration. 


\section{Inclusion Practices in French as a Second Language (FSL)}

For Dei (2006, as cited in Ontario Ministry of Education, 2009), "inclusion is not bringing people into what already exists; it is making a new space, a better space for everyone" (p. 2). Inclusivity in FSL programs, at minimum, refers to the access provided to children who have traditionally been marginalized from the program. However, inclusivity is also about reform and practices in the classroom. The issue of inclusivity in FSL programs (e.g., Allen, 2007; Mady, 2007; Mady \& Arnett, 2009) was previously discussed as a matter of suitability of learners for the program (e.g., Cummins, 1987; Genesee, 2006). In a recent article, Mady and Arnett (2016) examined how inclusivity has been a challenge to FSL programs in Canada. As they pointed out, there is not only some debate about who should be able to access these programs, but also how to practice and implement inclusivity. Despite this limitation, some FSL research has taken on a social justice slant in language education, moving from discussions of suitability to inclusivity (e.g., Arnett et al., 2014; Byrd Clark, Mady, \& Vanthuyne, 2014; Heffernan, 2011; Mady \& Black, 2012). To our knowledge, we have found only two studies that have focused on the perspectives of FI principals; therefore, the purpose of this study is to understand principals' views of ELL language learning, success, and inclusion in FI.

\section{The Study}

This study took place in a large urban school board in Southern Ontario reporting a population of over 50\% ELLs. In this school board, FI begins in Grade 1 after two years of Kindergarten in English. At this time, parents have the option to put their child's name into a lottery in order to be randomly selected to enroll in FI. The school board determines the number of places in FI available each year. The board limits enrollment in FI to $25 \%$ of the board's average enrolment. In addition, some schools have caps on FI enrollment due to space. The study was conducted with FI principals of elementary schools in the board. We used questionnaires and interviews to gather information regarding the inclusion of ELLs in FI.

\section{Participants}

All elementary FI principals, 41, in the board were invited via email to complete an online questionnaire on the inclusion of ELLs in FI. Fifty-nine percent of them $(N=24)$ responded to the questionnaire. Questionnaire respondents were overwhelmingly from dual track FI schools (96\%), with the one remaining principal from a single track FI school. The majority of principals (52\%) indicated that English and FI tracks in their schools were over

$50 \%$ ELL. Over one third of principals (35\%) estimated the number of ELLs in their school community to be over $50 \%$.

Fifty percent of those who responded to the questionnaire agreed to take part in follow-up interviews $(n=12)$. In one case, a vice-principal who had not responded to the questionnaire also sat in on the interview. All 13 interview participants will be referred to as "principals" throughout this study. They have been labeled as P1, P2, P3, et cetera, when reporting their responses throughout the study. The majority of the principals worked in K5 schools, save two who worked in K-8 schools. All of the interviewed principals indicated having learned French through schooling at some point in their lives. The average school 
population for these principals was 700 students, with school populations ranging from 500 to 900 students. The approximate average FI enrollment was 250 students, ranging from 90 to 400 students.

\section{Data Collection}

In this exploratory study, we used mixed methods to gather the data. First, we used a questionnaire with open and closed items to gather quantitative and qualitative data. Next, we invited a subset of principal volunteers for semistructured interviews. In addition, we consulted the board's website to examine one policy document containing information provided to parents about enrolling their children in FI.

The questionnaire consisted of three questions about the percentage of ELLs within the school and community contexts, with the option of providing additional information. A fourth question asked about the availability of English as a second language support for ELLs, followed by two open-ended questions asking principals to describe when they would include an ELL in FI and when, if ever, they would recommend that an ELL leave the FI track. These questions were followed by 12 questions using a Likert scale with five response options of $4=$ strongly agree, 3 = agree, $2=$ disagree, $1=$ strongly disagree, and not applicable $(N / A)$. See Table 1 below for the question items. The questions asked for principals' perspectives about ELLs' access, inclusion, and success in FI.

As noted in the Participants section, half of those who took part in the survey, that is to say 12 principals, and one vice-principal $(n=13)$ also took part in semistructured interviews. All principals were interviewed individually, except for one principal and viceprincipal pairing. The interviews were then transcribed by a research assistant immediately following each interview.

The interview protocol asked principals to go into more depth on the items that were touched upon in the questionnaire, such as (a) their personal language learning experiences, (b) their definition of success in FI for all and for ELLs specifically, (c) changes to inclusivity in FI over time, (d) ways offered to parents to access information on FI, (e) information provided to Kindergarten teachers regarding potential enrollment in FI, (f) situations where they would recommend an ELL transfer out of FI, (g) factors that inform a recommendation for an ELL to transfer to the English mainstream program, (h) contexts where they would recommend exemption from core French for an ELL, (i) means to determine ELLs' first language and English proficiency, (j) the purpose of transfers from FI to the English mainstream program, $(\mathrm{k})$ their knowledge about length of time to learn languages, and (1) how second language learning differs from third language learning.

\section{Data Analysis}

Our research focuses on exploring principals' ideologies about language and language learning. Ideologies are beliefs that have become mainstream within a given group and can be transmitted or shared with others (Roy, 2015). As Gee (2004) has pointed out, ideologies are expressed through different discourses, for instance texts, conversations, pamphlets, activities, and rituals and practices maintained within a particular context (in this case FI schools). We used critical discourse analysis (e.g., Fairclough, 2013; Gee \& Green, 1998) to explore principals' ideologies and beliefs about language learning and the way these interact with school policy and personal practice. Using a method of compare 
and contrast in Nvivo 11 software, we ran the ideologies from the school board's website and policy document against those that emerged across the principals' interviews, looking for any tensions, contradictions, or replications of the policy document discourse.

Data from the closed-item questionnaire component were tabulated to provide descriptive statistics of the principals' responses as shown in Table 1. The reported percentages are based on the total number of respondents to the questionnaire $(N=24)$. Responses where principals agreed or strongly agreed were amalgamated, as well as responses where principals disagreed or strongly disagreed. Due to the high number of principals who chose not to respond to the Likert scale portion of the questionnaire, a column tabulating the principals' abstention response rate was also included.

With $50 \%$ of principals volunteering to take part in the interview process, the interview data served as a means to further investigate principals' beliefs and ideologies about ELL inclusion in FI programs. The interview data were coded thematically in three phases. The first coding phase consisted of open coding. Items were coded in vivo (e.g., using the participants' phrasing) to identify principals' ideologies as they emerged across the interview sessions. This phase of analysis, rooted in grounded theory (Strauss \& Corbin, 1990), provided a picture of the different ideologies that emerge throughout the principals' discourses. The items were then grouped into topical nodes. In the second phase of coding, the data were sectioned and coded according to the questions from the interview protocol to determine how principals responded to the questions we set out to answer in the research.

The data were re-coded comprehensively and sorted into the nodes, this time corresponding to question items from the protocol. The final phase of data analysis consisted of a crosssectional analysis across principals' own answers and each other's answers. The nodes from the first and second phases of coding were examined for any tensions, contradictions, confirmations, and clarifications principals provided throughout the interviews to create a holistic picture of principals' beliefs about language learning, success, and inclusion in FI. The analysis consisted of quantifying the codes and drawing sample quotations.

The same process was carried out on a portion of the board's website that pertains to FI (i.e., an informational brochure) where we examined what discourses and ideologies were being promoted on the board website and in one official two-page PDF document created by the board and referred to by principals during this study's interviews when discussing options for FI with parents. Any references to policy or policy documents refer to this data; however, due to the revealing nature of the document and in order to preserve the anonymity of the school board, we will not be citing from it in this paper.

\section{Findings and Discussion}

In the findings, we first present the responses of the principals $(N=24)$ who participated in the Likert scale portion of the questionnaire (see Table 1). The questionnaire items have been grouped into three categories: beliefs about language learning, beliefs about ELL success in FI, and beliefs about ELL inclusion in FI programs. We will contrast and compare principals' ideologies and critically evaluate the findings from Table 1 by discussing them in conjunction with the responses provided by principals to open-ended items of the questionnaire, their contributions through subsequent interviews $(n=12+1$ vice-principal), and official board documents. 
Table 1

Questionnaire Responses from FI Principals $(\mathrm{N}=24)$

\begin{tabular}{|c|c|c|c|c|c|}
\hline \multirow[t]{3}{*}{ \# } & \multirow[t]{2}{*}{ Questionnaire Items } & \multicolumn{4}{|c|}{ Likert Scale Anchors } \\
\hline & & $\begin{array}{c}\text { Strongly } \\
\text { Agree/Agree } \\
(\%)\end{array}$ & $\begin{array}{c}\text { Strongly } \\
\text { Disagree/ } \\
\text { Disagree } \\
(\%)\end{array}$ & $\begin{array}{l}\text { N/A } \\
(\%)\end{array}$ & $\begin{array}{c}\text { No } \\
\text { Response } \\
(\%)\end{array}$ \\
\hline & Beliefs About Language Learning & & & & \\
\hline 1. & $\begin{array}{l}\text { I believe ELLs' focus should be the } \\
\text { acquisition of English. }\end{array}$ & 8.5 & 21 & 4 & 66.5 \\
\hline 2. & $\begin{array}{l}\text { I believe learning French is detrimental } \\
\text { to ELLs' learning of English. }\end{array}$ & - & 16.5 & - & 83.5 \\
\hline 3. & $\begin{array}{l}\text { I believe that the learning of French } \\
\text { will support the learning of English for } \\
\text { ELLs. }\end{array}$ & - & 8.5 & - & 91.5 \\
\hline 4. & $\begin{array}{l}\text { I believe ELLs are advantaged learning } \\
\text { French compared to their unilingual } \\
\text { Canadian peers. }\end{array}$ & 8.5 & 4 & 21 & 66.5 \\
\hline & Beliefs About Success in FI & & & & \\
\hline 5. & $\begin{array}{l}\text { ELLs meet with success in the English } \\
\text { mainstream program. }\end{array}$ & 8.5 & - & - & 91.5 \\
\hline 6. & $\begin{array}{l}\text { ELLs meet with success in the French } \\
\text { immersion program. }\end{array}$ & 21 & - & - & 79 \\
\hline 7. & $\begin{array}{l}\text { Success in French immersion requires a } \\
\text { certain level of English competency. }\end{array}$ & 4 & 17 & - & 79 \\
\hline 8. & $\begin{array}{l}\text { I believe the parents of ELLs support } \\
\text { their learning of French. }\end{array}$ & 8.5 & 4 & 4 & 83.5 \\
\hline & Inclusion in FI & & & & \\
\hline 9. & $\begin{array}{l}\text { My French immersion teachers are } \\
\text { prepared to meet the needs of ELLs. }\end{array}$ & 17 & 4 & - & 79 \\
\hline 10. & $\begin{array}{l}\text { ELLs should be included in French } \\
\text { immersion. }\end{array}$ & 17 & - & - & 83 \\
\hline 11. & $\begin{array}{l}\text { In French immersion, the presence of } \\
\text { ELLs has an unfavourable impact on } \\
\text { the learning potential of the other } \\
\text { students in the class. }\end{array}$ & - & 17 & - & 83 \\
\hline 12 . & $\begin{array}{l}\text { There are occasions when an ELL } \\
\text { should be exempt from learning } \\
\text { French. }\end{array}$ & 16.5 & 8.5 & 4 & 71 \\
\hline
\end{tabular}

Note. Questionnaire Instructions: "Indicate your level of agreement/disagreement with the following statements." Dash (-) indicates 0\%.

Questionnaire responses overwhelmingly showed over $60 \%$ of principals abstaining from agreeing or disagreeing with items about language learning, ELL success in FI, and 
inclusion in FI programs on any given item. This suggests that either these issues are complex and require deeper consideration than a survey can provide, or principals have not formed or are not willing to share particular opinions around these ideas about language learning, success, and inclusion. In some cases, principals did respond to open-ended items on the questionnaire that invited more nuanced responses. We will discuss these within each section below. The sections mirror the three sections of the questionnaire and include item numbers in parentheses when referencing the questionnaire.

\section{Principals' Beliefs About Language Learning}

The questionnaire reveals that while $21 \%$ disagree, $8.5 \%$ of principals believe ELLs should focus on the acquisition of English. This suggests diametrically opposed perspectives about language learning for ELLs, with a large group of principals $(66.5 \%)$ who did not express themselves on the matter (item \#1). We probed into these ideologies further during the interviews with 13 principals. Almost half $(n=5)$ felt it was important to learn English before French:

We get kids that are ELLs later, maybe new arrivals to Canada. I think at that time the load is a little bit different and maybe developmentally it's a little more challenging for them, so I would say that their needs as a student may be better served in that core French environment. (P2)

In some cases, learning English is perceived as a prerequisite to learning French for ELL success. As one principal explained: "Some students can cope fine in core French, some students will cope well in FI, it just depends on the level of English" (P10). The ideas expressed here show that some principals are sorting and prioritizing languages for ELLs. What is more, English seems to be a requirement for ELLs in the FI program where principals feel the students should master English before French. On the other hand, three principals advocated for learning French and English simultaneously. As one of them explained: "I think if they are able to maintain the first language, learn English, and learn French at the same time, I think that would be a huge bonus" (P1). For these principals, languages can be learned and maintained simultaneously, and success depends on the support learners have with each one. Principals revealed oppositional beliefs about ELL language learning in the FI program, some seeing English as linked to learning French and others not.

In the questionnaire, $16.5 \%$ of principals disagreed with the idea that learning French is detrimental to learning English, while $83.5 \%$ abstained from responding to the question (item \#2). Interestingly, none of the principals indicated believing that learning French can help to learn English; in fact, 8.5\% disagreed and 91.5\% abstained from responding (item \#3). This prompted further questions about principals' understanding of multilingualism. When asked about this in the interviews $(n=13)$, just over half of principals $(n=7)$ felt that it was harder to learn a second language than a third language. As one principal stated: "The second language learning is the hardest. Once you've got the second language, you transfer a lot of those skills to the other languages" (P13). Two principals felt there was no difference, while a single principal felt that learning a second language is easier than learning a third. The data show that principals, who inform language 
policy practices in their schools, have a wide array of, at times contradictory, beliefs about language learning.

In another item exploring principals' beliefs about multilingualism, data from the questionnaire show that roughly one in five principals $(21 \%)$ do not believe that being a multilingual speaker (i.e., an ELL) has any bearing on learning French, while 8.5\% agree that ELLs have an advantage and 4\% disagree (item \#4). When asked about learning multiple languages during the interviews, four principals expressed the belief that it is easier to learn additional languages if they are from the same language family. They also indicated that learners could benefit from cross-linguistic transfer. Six principals also expressed the idea that having prior language learning experience is an asset. For some, ELLs have a metalinguistic advantage over their non-ELL peers because they are already familiar with the process of learning an additional language. As one principal clarified: "I think with the more languages a child learns, the more they have to draw from in terms of strategies to learn languages" (P8). Four principals, however, expressed a dissenting view, claiming that learning several languages simultaneously can be too overwhelming. Two principals expressed the idea thus: "They mix up languages, you see them sometimes using English and French and their own language so it is confusing for them" (P5) and "They're too young to handle it at this point" (P10).

These principals echoed the sentiment found in the common sense principle (Cummins, 2007), promoting the separation of different languages and equal level of fluency and development in all languages. This can be problematic for multilingual learners who do not always progress at the same rate across languages (Grosjean, 1982). For instance, learners who do not transition between languages seamlessly might be deemed "confused." The impact of such an ideology in the FI program means that learners who do not show progress at the same rate as their peers or at the same rate across different languages can be labeled "unsuccessful" students in the FI program. As the data below indicate, children perceived this way are then sometimes encouraged to leave the FI program. In their work, Flores and Rosa (2015) cautioned against discourses about ELLs' language ability that result in what they term the appropriateness-based model:

Appropriateness-based models advocate teaching language-minoritized students to enact the linguistic practices of the white speaking subject when appropriate, the white listening subject often continues to hear linguistic markedness and deviancy regardless of how well language-minoritized students model themselves after the white speaking subject. (p. 152)

Not understanding that ELLs may come to the standard language at varying rates of progress exhibiting non-standard patterns of learning can result in stigmatizing ELLs for their multilingual pathway to learning French.

When it comes to multilingual learners, six principals also indicated the importance of ELLs having strong literacy skills in their home language. As one principal disclosed: "So many of our language learners don't have a grounded mother tongue, so I think it all ties in" (P2). Although schools do not assess home language proficiency, as one principal put it: "Whether they have enough strengths in both their home language and in English to take on a third" (P3) seems to play a role in determining if ELLs should stay in the FI program. When principals were asked to report on any home language assessment or support in schools, they admitted that their schools did not assess or monitor home 
language skills. It seems principals who recognize the value and the importance of acknowledging ELLs' multilingual repertoires are not necessarily given the tools to support home language assessment/maintenance. Further, rather than exploring the possibility of incorporating their students' linguistic and cultural capital into their schooling experience, it appears that principals view home language maintenance as the responsibility of the home.

Research has shown that gatekeepers often base decisions on personal beliefs and experiences (e.g., Arnett et al., 2014; Arnett \& Turnbull, 2008). To understand principals' beliefs about language learning, and how these might shape their language policy in schools, during the interviews we asked them about their personal experiences with learning languages, and their professional experiences working with students learning multiple languages either at home or at school. Despite all of the interviewed principals indicating they had learned French at school at some point in their lives, only two of the 13 principals self-identified as bilingual. Two others expressly identified as monolingual. Among the remaining nine principals who had experience with two or more languages, none of them identified as bilingual or multilingual. In fact, these principals judge their language knowledge as deficient, rather than as a resource. These principals do not express confidence in their bilingualism and view it as a "glass half-empty" situation, as this quotation from P1 illustrates: "Even though I took it all the way through, because I don't have many opportunities to use French, my French is not very good." In his work, Grosjean $(1982,1985,2014)$ has argued that bilingualism is the use of two (or more) languages in one's daily life, not the use two (or more) languages at high level. The implied ideology among these principals represents this common misconception about bilingualism. The findings suggest that their meaning for the word bilingual entails that one must speak both languages with the same fluency; that is, they equate bilingualism with "equalingualism" (Grosjean, 1982). This may account for the fact that nine out of 12 principals did not label themselves as bilingual. Gatekeepers confusing bilingualism with equalingualism can have unintended negative impacts in the school environment. For one, it does not acknowledge the multilingual repertoires that exist in the school (if languages are only recognized once they are equally mastered). Next, it positions language learners as deficient rather than multicompetent, (i.e., members able contribute to the school linguistic environment). Finally, it does not recognize language learning as a dynamic process in which leaners are continuously structuring and restructuring their language repertoires to adapt to their daily needs and experiences.

\section{Principals' Beliefs About Success in French Immersion (FI)}

We asked principals to define success in general terms during the interview process $(n=13)$. Principals defined success as communicative competence and emotional wellbeing for students in the program. For principals, learners in the FI program need to produce visible, measurable results in terms of competency skills such as communicating, reading, thinking, and speaking. Principals' views on success are tied to ability. For instance, principals defined success thus: "You're able to read and write with some proficiency" (P4) and "Success would be the student's ability to speak French: that they comprehend, that they can converse" (P7). Another important part of success is marked by the learners' emotional wellbeing or how well learners adjust to the classroom environment. For example, one principal said this: "A child shows an energy and an 
excitement for the language and even starts to ask questions about the culture of the language that they're experiencing" (P2). Another principal commented: "What I want to see are kids that are engaged in their program who have a love of the language, who want to speak French" (P5).

Interestingly, a greater percentage of principals agreed to say that more ELLs met with success in the FI program (21\%) than in the English program (8.5\%, items \#5 and \#6). Given that ELLs have traditionally been excluded from FI programs on the grounds that learning too many languages is too difficult (Calman, 1988) or that mastery of English is required before learning French (Mady, 2006), it is curious to see that almost three times as many principals feel that a higher number of ELLs meet with success in the FI program than in the English program. This does, however, confirm recent research which suggests that ELLs can be as successful in FI, if not more so, as their Canadian ${ }^{2}$ counterparts (e.g., Mady, 2015). None disagreed with the statement; however, the abstention rate was high, with $91.5 \%$ for the English program item and $79 \%$ for the FI program item.

All the principals interviewed $(n=13)$ agreed that the criteria and goals for success in the FI program are officially the same for ELLs and non-ELLs. The majority $(n=8)$, however, noted concessions to keep in mind when working with ELLs. Four principals believed ELLs might take longer to learn additional languages: "It does take slightly longer" (P8) and "It's just that sometimes we panic that they're not progressing at the same rate as a child that's only battling with one language system" (P9). Among our interview participants, one principal noted the importance of maintaining simultaneous progress in English and the home language. This principal defined success "somewhat similarly with the exception to be, I think, it's very important that they maintain the progress in English as well as their mother tongue" (P11). Another principal highlighted the importance of maintaining literacy and reading skills: "That would be the same criteria but they can read fluently and you are seeing progress in that reading" (P12). The reasoning behind this additional criterion seems to have been the school's practice of measuring success through standardized reading test scores. Concessions to the nature and definition of success for ELLs in FI programs suggest further exploration is needed to uncover why these concessions exist. The data indicate that principals recognize that coming to the FI program as a multilingual speaker signals different needs and abilities from non-ELL students. However, the Ontario Education Act (1990) limited instruction in Ontario public schools to English and French, meaning educators cannot officially explore the very component that they express matters in ELLs' success: their home language.

Parental engagement is another area where contradictory discourses emerge. On one hand, in the questionnaire, only $8.5 \%$ of principals agree that parents of ELLs support their children learning French (item \#8). Meanwhile 4\% disagree and 83.5\% abstained from responding. On the other hand, other research has found principals to be aware that immigrant families are very committed to their children learning French as a means of social mobility in Canadian society (Dagenais et al., 2006). Principals are also aware of ELL families' perspectives on FI programs, as this quotation from an open item on the questionnaire illustrates: "Our immigrant families strongly believe that their children have a better chance of being successful in Canada if they are fluent in both English and French." However, research on immigrant parental involvement in schools suggests that their expectations do not always match those of the school, creating tension (Dyson, 2001; Guo, 2006). There is evidence that concerted efforts between schools and immigrant parents can improve home-school communication and relationships (Ladky \& Peterson, 2008). One 
principal, during the interviews, hinted at the type of parental commitment needed for the program: "It depends on the individual student and their parents' commitment to the FI program. The students need to be at school and they would benefit by attending French camps and milieus during the summer" (P7). As this principal explained, "For some of our kids, they leave Canada for a couple of months and then they come back. They are immersed in another language and culture. They miss the immersion in the French language and need to re-adapt" (P7). These comments reveal some tensions surrounding time and financial commitment to FI. The idea that ELLs should not experience immersion in other languages and cultures so as to not disrupt immersion in the FI program during the school year overlooks the emotional investment multilingual families have to languages other than French and English. At the same time, the idea that parental commitment involves sending their children to French-speaking camps during extracurricular periods (i.e., the summer) creates additional financial requirements, and bypasses the issue of time multilingual families need to spend in other language environments.

There is also a sentiment, explicitly expressed by two principals during the interviews, that parents are "forcing" their children to be in the program when principals do not necessarily feel that these parents' children should be in the program. As one principal stated: "Today, no one is excluded. The students have the right to fail in French, only the parents can pull them out of FI" (P6). This prompts questions about how well these students, who are perceived as "not belonging" in the program, are supported by the administration to succeed. In contrast, another principal expressed an explicit desire to respect parents' choices: 'In our system it's a parent's decision about whether or not a child is in the FI program and if that child is in the program I am going to do my very best to support that parent's decision to have the child in the program" (P4).

Another puzzling result from the survey reveals that $17 \%$ of principals disagree with the idea that success in FI requires a certain level of English competency (item \#7). Meanwhile $4 \%$ of principals agree, echoing a sentiment shared by $21 \%$ of principals (item \#1) who felt that ELLs should focus on learning English. Again, about one in five principals place themselves at either end of the spectrum when it comes to determining the place of English for ELLs in FI programs.

To understand more about how principals defined success in the FI program, we asked them about their perceptions of the ideal language learner. The board's website offers information to parents who are considering registering their child in FI. The site provides a list of seven characteristics of children who have been successful in FI. The same seven characteristics are also included in the parental brochure, which is available from the site. The site and brochure encourage parents to speak to their child's Kindergarten teacher. Given that the identity of the board would be revealed with specific references and direct citations, this document analysis is limited to commonalities and differences found between the principals' perspectives and those characteristics of successful FI students as identified by the board.

Despite official policy that all children have access to FI through the lottery system, interviews with principals revealed an image of an ideal learner profile that persists among principals and in some cases their teaching staff: "There are many FI teachers who feel that only a certain type of student should be in French: a student who's well-behaved, does very well academically" (P11). The same discourse about academic and social functioning is present in the school website and brochure. The idea that only well-behaved children should be accepted into the FI program is also one that is maintained by eight principals. 
For these principals, the inclusive policy presents a challenge because it allows students whose profile does not match that of the ideal learner entry into the FI program. Here is one representative comment:

I went in to talk with each of the individual principals about all of the kids that were coming in and I know that one of the principals has a number of youngsters, three in particular, who are coming who are apparently very very challenging students, behaviourally and academically, and I know that that principal felt that she didn't have the right to tell parents that this may not be an appropriate program for the child. (P5)

Table 2 lists features of the ideal FI learner profile that emerged throughout the interviews. It is similar to the list of characteristics presented to parents on the board's site, suggesting that principals are echoing a board-wide policy.

Table 2

Principals' Ideal Learner Profile for Entering French Immersion Program Based on Interview Data

\begin{tabular}{ll}
\hline Criteria for Ideal Learner Profile & $\#$ of Principals \\
\hline Verbal (likes to talk) & 6 \\
Strong literacy skills & 5 \\
Risk taker & 5 \\
Enjoys new challenges & 3 \\
Level of English & 3 \\
Interested in learning the other language & 3 \\
Capacity for learning language & 3 \\
Family engagement & 3 \\
High self esteem & 2 \\
Imitates easily & 2 \\
Learning skills & 2 \\
Transitioned successfully from home to school & 2 \\
Responding to teacher & 2 \\
Other & 1 \\
\hline
\end{tabular}

${ }^{a}$ Other factors include: being independent, sitting attentively in class, having strong skills in home language, having a good memory, capacity for abstract thinking and aural ability.

All of the principals acknowledged the official policy of allowing everyone access to the FI program. A majority of them $(n=8)$, however, also maintained a counter-discourse through the means of an ideal learner profile, which is also being used to filter who would be recommended to apply to or discouraged from staying in the program. Findings in the interview data indicate this occurs in three ways, outlined in the following section.

\section{Inclusion in French Immersion (FI) for English Language Learners (ELLs)}


Principals' perceptions of their communities mirror the information provided by Statistics Canada (2016) indicating that immigrant populations are rising in major urban centres. Principals indicated having at least $50 \%$ of their student population coming from recently arrived immigrant families and an increase in ELLs accessing FI programs, reflecting the changing linguistic ecologies of FI classrooms.

Items pertaining to inclusion on the questionnaire indicated that $17 \%$ of principals believe that ELLs should be included in FI, with the remaining 83\% abstaining from responding (item \#10). The same number of principals (17\%) feel that ELLs' presence is not detrimental to other learners in the FI program; however, $83 \%$ of principals abstained from responding to this question as well (item \#11). In the open items on the questionnaire, principals were asked what considerations they take into account when thinking about including ELLs in FI. Seventeen principals offered seven different considerations. On one hand, the majority of responding principals $(n=11)$ indicated not having influence on intake to FI. The most frequent response $(n=6)$ indicated that the decision was that of the parents and did not involve the administration. Similarly, three principals revealed that considerations were no different among students as the lottery system in place provides equitable opportunity for access. Likewise, two principals indicated that all students were eligible to enroll in FI. On the other hand, five principals indicated English and/or other language proficiency as a consideration for FI enrollment. Other considerations included the students' emotional and mental wellbeing and positive beliefs in their language learning abilities.

In the questionnaire responses, only $17 \%$ of principals feel that FI teachers are prepared to meet the needs of ELLs, while 4\% disagree and 79\% of principals abstained from responding (item \#9). Principals were asked during the interview if they experienced a change in inclusive practices in FI over time and, if so, to describe them. Eleven principals noted a significant change in the inclusivity of the FI programs in recent years. However, the change is marked as inclusive by who is accessing the program, not necessarily changes in the FSL program itself. As one principal explained: "It's just who we have. So there's not a huge shift because it's who we have in our school" (P8).

When it comes to exempting ELLs from learning French, regardless of program, $16.5 \%$ of principals who answered the questionnaire believe it is sometimes necessary while $8.5 \%$ disagree with the need for such an exemption. In response to an open-ended item on the questionnaire asking what they would consider if and when they encourage ELLs to change to the English stream, 17 principals offered six different responses. In the most frequent response $(n=10)$ principals consider students' progress in English and French, echoing the common sense principle, demonstrating how deeply the monolingual bias is embedded in ideas about language learning. Four principals revealed affective considerations (e.g., motivation, confidence), while two principals invoked learning challenges and first language fluency. Two principals indicated that they would not be making recommendations to remove an ELL from the FI stream. Therefore, although the majority of principals accepted limited inclusive access to FI as provided by the lottery system, there were times after entry when they considered whether a child would be better served in the English program, English language communicative competencies being given priority.

However, one of the shifts brought about by encouraging inclusion through the lottery system and recent FSL policy documents (e.g., Ontario Ministry of Education, 2016) 
is that the principals feel that they and their teachers have less of a say in whether or not ELLs should stay in the FI program.

I think that many years ago, even though it was always sort of supposed to be very open to all students that if they found, during the course of that first year that the students were not settling into the program, they [the teachers] had more of a comfort level to approach the parents to say, we don't think this is right for your child. Whereas now the message I give them is that we have to be honest with the parents about how the children are doing and whether they are being successful or not, successful in what we're seeing them and what we're not seeing from them if they're not successful, but that we can't coach parents to withdraw children from the program, they need to make their own decisions. (P5)

Two principals expressed concern over the fact that the inclusive policy may mean that there are students who are forced to be in the program by their parents:

What I'm hearing from them [teachers] is that there are a lot of children who are coming into the program because their parents want them in the program and who are staying in the program because their parents want them in the program, where they're not necessarily enjoying the program. (P5)

Three principals also noted that making FI more inclusive is perceived as an opportunity by parents:

I'm thinking that there are more parents of children who are ELLs who are choosing this option for their children and they see it as an opportunity probably more than when I was teaching at the beginning of my career. (P8)

Principals have noted a difference in the linguistic ecology of the classroom, leading to some uncertainty about how to deal with inclusivity in FI programs if students are unhappy or parents are seeking counsel, especially since some immigrant families perceive FI as an opportunity for their children and would like them to succeed in the program.

Analysis of the interview data reveals that the practices principals advocate or observe in their schools set the tone for the Grade 1 recruitment of students to FI. Three practices emerged: active recruitment or discouragement, passive recruitment or discouragement, and refraining from taking a position. Five of the 12 principals revealed not having any formal conversations with teachers about how to talk with parents about their children enrolling in FI. Two principals indicated that their conversations are limited to "logistics" (e.g., what papers to hand out, when to meet with parents).

Active recruitment or discouragement. Some principals reported observing students being actively being recruited or discouraged from joining the FI program based on teachers' perceptions of fit to the ideal learner profile:

Parents will approach them [teachers] about, should my child go to FI and sometimes the teachers will say that they don't feel [that the program] will be successful for their child. (P1) 
In some cases, the principals' policy with teachers is to provide explicit advice to parents telling them whether or not they think their child should be in FI, if principals or teachers are approached:

We don't necessarily approach parents to say hey, we think your child would be a good candidate for FI, if parents are asking us about it though, we do give our professional opinion whether we think the likelihood of their child having success in FI is high. (P11)

Passive recruitment or discouragement. In some situations, the ideal learner profile is promoted to parents and they are left to decide if their child should enter the program based on these characteristics: "So we're looking for children who like to mimic, can copy, take risks, they're not shy or hesitant, and of course for me the key thing is the reading piece" (P12). And, as another participant described:

I also encourage parents to be discussing with the kindergarten teachers whether or not they feel their child would be an appropriate candidate for the FI program, because you need to be a risk-taker and you need to be outgoing and you need to not be afraid to be talking in front of other people. (P5)

Refraining from taking a position. In three cases, the principals' policy with teachers is to explicitly refrain from recommending or not that children enter the FI program. They limit themselves to discussing the individual child's progress at school.

\section{Conclusion}

Since the 1990s, Canada has welcomed approximately 200,000 new immigrants every year (Statistics Canada, 2014), representing more than 200 ethnic origins, $75 \%$ of whom are multilingual (Statistics Canada, 2013). Immigrants and their families contribute to multiculturalism in the Canadian social fabric, creating more networks between people of different languages and cultures. Principals would benefit from expanding their view of multilingual learners' experiences with languages by looking at language as social capital, not only economic or linguistic capital (Bourdieu, 1986). However, working and living in an English-dominant environment shapes principals' ideologies about learning additional languages and in what order this should occur. For instance, the data suggest that principals believe that English ability for ELLs matters in the FI program, whereas English competency is not questioned for non-ELL students. This is an issue of contention for FI principals when it comes to ELLs, and it influences how access and inclusion to FI play out in the program.

While the benefits of multilingual education are advocated in research and policy documents, "these official discourses are often more myth than reality as far as educational practice is concerned" (Duff, 2007, p. 150). In fact, the discourse of principals in this study reveals this discrepancy. Policy ideas are understood and applied, but these ideas do not always align with principals' own understanding of what bilingualism or multilingualism are and what they entail for ELLs. Possible considerations for principals of FI programs would be to develop understanding about multilingualism and creating inclusive 
environments for ELLs. Pluralistic approaches to language may offer means by which inclusive practices for ELLs in FI could extend from policy to program adaptations (e.g., Auger, 2008). For ELLs, inclusivity in FI implies a move from monolingual to multilingual approaches to acknowledge the existence of languages beyond official languages of instruction as supports for learning. Adapting FI programs to the needs of ELLs would require dissemination of information dispelling the myths of the ideal language learner and the common sense principle by providing professional development for principals and teachers on adopting multilingual approaches to the classroom and to their own perceptions of language and learning.

Principals need further discussion about where their beliefs come from and why they hold such positions on language learning. As Cummins suggested (2007, 2014), educators need to rethink assumptions about language learning and consider the differences in learning and teaching strategies in multilingual classrooms in order to create FI programs that best serve classrooms populated by learners who have different linguistic repertoires upon which to draw. The discourses principals maintain about language learning influence language policy in schools and play a role in determining perceptions of the ideal language learner and their definition for success.

Correspondence should be addressed to Callie Mady.

Email: calliem@nipissingu.ca

\section{Notes}

${ }^{1}$ French as Second Language (FSL) is taught across Canada through the delivery models of core French, extended French, French immersion (FI), and Intensive French. Core French is the study of the language for one daily period of approximately 40 minutes. Students enrolled in extended French and FI study content in French for $25 \%$ of the day in the former and a minimum of $50 \%$ of the day in the latter. Intensive French is a program in which French is taught intensively for most of the day during five months in Grade 5 or 6.

${ }^{2}$ For the purposes of this study, English language learners (ELLs) refer to immigrant students who are adding English and French to their language repertoires.

\section{References}

Allen, D. (2007). Just who do you think I am? The name-calling and name-claiming of newcomer youth. Canadian Journal of Applied Linguistics/Revue canadienne de linguistique appliquée, 10(2), 165-175.

Antón, M., \& DiCamilla, F. (1998). Socio-cognitive functions of L1 collaborative interaction in the L2 classroom. Canadian Modern Language Review, 54(3), 314342 .

Arnett, K., Mady, C., \& Muilenburg, L. (2014). Canadian FSL teacher candidate beliefs about students with learning difficulties. Theory and Practice in Language Studies, 4(3), 447-457.

Arnett, K., \& Turnbull, M. (2008). Teacher beliefs in second and foreign language teaching: A state-of-the-art review. In J. Siskin (Ed.), From thought to action: 
Exploring beliefs and outcomes in the foreign language program (pp. 9-28). Boston, MA: Thomas Heinle.

Auger, N. (2008). Favoriser le plurilinguisme pour aider à l'insertion scolaire et sociale des élèves nouvellement arrivés (ENA). Glottopol, 11, 126-137.

Bourdieu, P. (1986). The forms of capital. In J. Richardson (Ed.), Handbook of theory and research for the sociology of education (pp. 241-258). Westport, CT: Greenwood.

Bourgoin, R. (2016). French immersion "so why would you do something like that to a child?": Issues of advocacy, accessibility, and inclusion. International Journal of Bias, Identity and Diversities in Education (IJBIDE), 1(1), 42-58.

Byrd Clark, J., Mady, C., \& Vanthuyne, A. (2014). Exploring reflexivity and multilingualism in three French language teacher education programs. Canadian Journal of Applied Linguistics/Revue canadienne de linguistique appliquée, 17(1), 129-155.

Calman, R. C. (1988). Core French program review, grades 3-8: Technical report. Willowdale, ON: North York Board of Education.

Canada, Department of Justice. (1969). Official languages act. Ottawa, Ontario, Canada: Government of Canada.

Cummins, J. (1987). Immersion programs: Current issues and future directions. In L. L. Stewin \& S. J. H. McCann (Eds.), Contemporary educational issues: The Canadian mosaic (pp. 192-206). Toronto, ON: Copp Clark Pitman.

Cummins, J. (2007). Rethinking monolingual instructional strategies in multilingual classrooms. Canadian Journal of Applied Linguistics/Revue canadienne de linguistique appliquée, 10(2), 221-240.

Cummins, J. (2014). Rethinking pedagogical assumptions in Canadian French immersion programs. Journal of Immersion and Content-Based Language Education, 2(1), 3 22.

Dagenais, D. (2003). Accessing imagined communities through multilingualism and immersion education. Journal of Language, Identity, and Education, 2(4), 269-283.

Dagenais, D. (2013). Multilingualism in Canada: Policy and education in applied linguistics research. Annual Review of Applied Linguistics, 33, 286-301.

Dagenais, D., \& Berron, C. (2001). Promoting multilingualism through French immersion and language maintenance in three immigrant families. Language Culture and Curriculum, 14(2), 142-155.

Dagenais, D., Day, E., \& Toohey, K. (2006). A multilingual child's literacy practices and contrasting identities in the figured worlds of French immersion classrooms. International Journal of Bilingual Education and Bilingualism, 9(2), 205-218.

Dagenais, D., \& Moore, D. (2008). Représentations des littératies plurilingues, de l'immersion en français et des dynamiques identitaires chez des parents chinois. Canadian Modern Language Review, 65(1), 11-31.

Duff, P. A. (2007). Multilingualism in Canadian schools: Myths, realities and possibilities. Canadian Journal of Applied Linguistics, 10(2), 149-163.

Dyson, L. L. (2001). Home-school communication and expectations of recent Chinese immigrants. Canadian Journal of Education/Revue canadienne de l'éducation, 455476.

Education Act, RSO 1990, c. E.2. Retrieved from https://www.canlii.org/en/on/laws/stat/ rso-1990-c-e2/latest/rso-1990-c-e2.html 
Fairclough, N. (2013). Critical discourse analysis: The critical study of language. New York, NY: Routledge.

Flores, N., \& Rosa, J. (2015). Undoing appropriateness: Raciolinguistic ideologies and language diversity in education. Harvard Educational Review, 85(2), 149-171.

Gee, J. P. (2004). Situated language and learning: A critique of traditional schooling. New York, NY: Routledge.

Gee, J. P., \& Green, J. L. (1998). Discourse analysis, learning, and social practice: A methodological study. Review of Research in Education, 23, 119-169.

Genesee, F. (2006). The suitability of French immersion for students who are at risk: Students with special needs and lower academic ability. Ottawa, ON: Canadian Parents for French. Retrieved from http://www.psych.mcgill.ca/perpg/fac/genesee/Suitability of Immersion for At-Risk Students.pdf

Grosjean, F. (1982). Life with two languages: An introduction to bilingualism. Cambridge, MA: Harvard University Press.

Grosjean, F. (1985). The bilingual as a competent but specific speaker-hearer. Journal of Multilingual \& Multicultural Development, 6(6), 467-477.

Grosjean, F. (2014). Bicultural bilinguals. International Journal of Bilingualism, 572-586.

Guo, Y. (2006). Why didn't they show up? Rethinking ESL parent involvement in K-12 education. TESL Canada Journal, 24(1), 80-95.

Hefferman, P. J. (2011). Second-language (L2) teacher preparation and ongoing professional development in a world in need of social justice. Journal of Interdisciplinary Education, 10(1), 142-155.

Heller, M. (2003). Globalization, the new economy, and the commodification of language and identity. Journal of Sociolinguistics, 7(4), 473-492.

Hermanto, N., Moreno, S., \& Bialystok, E. (2012). Linguistic and metalinguistic outcomes of intense immersion education: How bilingual? International Journal of Bilingual Education and Bilingualism, 15(2), 131-145.

Ladky, M., \& Peterson, S. S. (2008). Successful practices for immigrant parent involvement: An Ontario perspective. Multicultural Perspectives, 10(2), 82-89.

Lambert, W. E., \& Tucker, G. R. (1972). Bilingual education of children: The St. Lambert experiment. Rowley, MA: Newbury House.

Lazaruk, W. (2007). Linguistic, academic, and cognitive benefits of French immersion. Canadian Modern Language Review, 63(5), 605-627.

Mady, C. (2006). The suitability of core French for recently arrived English as a second language adolescent immigrants (Unpublished doctoral dissertation). University of Toronto, Toronto, ON. Retrieved from https://tspace.library.utoronto.ca/

Mady, C. (2007). Allophone students in French second-official-language programs: A literature review. Canadian Modern Language Review, 63(5), 727-760.

Mady, C. (2012a). Official language bilingualism to the exclusion of multilingualism: Immigrant student perspectives on French as a second official language in 'Englishdominant' Canada. Language and Intercultural Communication, 12(1), 74-89.

Mady, C. (2012b). Voices of immigrant adults: Perspectives and experiences with French as a second official language in "English-dominant" Canada. Intercultural Promenades: Journal of Modern Languages and International Studies, 1(1), 35-51.

Mady, C. (2014a). Immigrant status as an influential factor in additional language learning: A comparison of French language achievement of Canadian-born monolinguals, 
bilinguals and bilingual immigrants. Journal of Language Teaching and Research, $5(1), 12-20$.

Mady, C. (2014b). Learning French as a second official language in Canada: Comparing monolingual and bilingual students at Grade 6. International Journal of Bilingual Education and Bilingualism, 17(3), 330-344.

Mady, C. (2015). The bilingual advantage for immigrant students in French immersion in Canada: Linking advantages to contextual variables. International Journal of Bilingual Education and Bilingualism, 1-17.

Mady, C., \& Arnett, K. (2009). Inclusion in French immersion in Canada: One parent's perspective. Exceptionality Education International, 19(2), 37-49.

Mady, C., \& Arnett, K. (2016). French as a second language teacher candidates' conceptions of Allophone students and students with learning difficulties. Canadian Journal of Applied Linguistics/Revue canadienne de linguistique appliquée, 18(2), 78-95.

Mady, C., \& Black, G. (2012). Access to French as second official language programs in English-dominant Canada. Alberta Journal of Educational Research, 57(4), 498501.

Milley, P., \& Arnott, S. (2016). The nature of principals' work and leadership in French as a second language learning in Ontario schools. Canadian Journal of Education, $39(1), 1-26$.

Ontario Ministry of Education. (2009). Realizing the promise of diversity: Ontario's equity and inclusive education strategy. Toronto, ON: Queen's Publisher. Retrieved from http://www.edu.gov.on.ca/eng/policyfunding/equity.pdf

Ontario Ministry of Education. (2016). Welcoming English language learners into French as a second language programs. Toronto, ON: Ontario Ministry of Education. Retrieved from http://www.edu.gov.on.ca/eng/amenagement/welcoming.pdf

Pavlenko, A. (2006). Emotions and multilingualism. Cambridge, United Kingdom: Cambridge University Press.

Roy, S. (2012). Qui décide du meilleur français ? Représentations des variétés linguistiques du français en immersion. Canadian Journal of Applied Linguistics, 15(1), 1-19.

Roy, S. (2015). Discours et idéologies en immersion française. Canadian Journal of Applied Linguistics/Revue canadienne de linguistique appliquée, 18(2), 125-143.

Rubin, J. (1975). What the "good language learner" can teach us. TESOL Quarterly, 9(1), 41-51.

Sridhar, K. K. (1996). Societal multilingualism. In S. L. McKay \& N. H. Hornberger (Eds.), Sociolinguistics and language teaching (pp. 47-70). Cambridge, United Kingdom: Cambridge University Press.

Statistics Canada. (2013). Immigration and ethnocultural diversity in Canada. Ottawa, ON: Ministry of Industry. Retieved from http://www12.statcan.gc.ca/nhs-enm/2011/assa/99-010-x/99-010-x2011001-eng.pdf

Statistics Canada. (2014). Permanent residents, 1860 to 2014. Ottawa: ON: Citizenship and Immigration Canada. Retrieved from http://open.canada.ca/data/en/dataset/2fbb56bd-eae7-4582-af7d-a197d185fc93

Statistics Canada. (2016). Immigration and ethnocultural diversity in Canada. Ottawa: ON: Citizenship and Immigration Canada. Retrieved from https://www12.statcan.gc.ca/nhs-enm/2011/as-sa/99-010-x/99-010-x2011001eng.cfm 
Stern, H. H. (1975). What can we learn from the good language learner? Canadian Modern Language Review 31(4), 304-318.

Stern, H. H., Swain, M., McLean, L. D., Friedman, R. J., Harley, B., \& Lapkin, S. (1976). Three approaches to teaching French: Evaluation and overview of studies related to the federally funded extensions of the second language learning (French) programs in the Carleton and Ottawa school boards. Toronto, ON: Ontario Institute for Studies in Education.

Strauss, A., \& Corbin, J. (1990). Basics of qualitative research. Los Angeles, CA: Sage.

Swain, M., \& Lapkin, S. (2000). Task-based second language learning: The uses of the first language. Language Teaching Research, 4(3), 251-274.

Swain, M., \& Lapkin, S. (2002). Talking it through: Two French immersion learners' response to reformulation. International Journal of Educational Research, 37(3), 285-304.

Thomas, R., \& Mady, C. (2014). Teaching for transfer: Insights from theory and practices in primary-level French-second-language classrooms. McGill Journal of Education/Revue des sciences de l'éducation de McGill, 49(2), 399-416.

Tipurita, M.-E., \& Jean, G. (2014). Enseignement explicite du genre des noms en français : expérimentation au primaire en classe d'immersion. Canadian Modern Language Review, 70(3), 279-302.

Turnbull, M. (2001). There is a role for the L1 in second and foreign language teaching, but.... Canadian Modern Language Review, 57(4), 531-540.

Turnbull, M. (2008, May). School principals'views on FSL programs in Canada. Paper presented at the Centre Canadien d'Études et de Recherche en Bilinguisme et Aménagement Linguistique, Ottawa, ON.

Turnbull, M., Cormier, M., \& Bourque, J. (2011). The first language in science class: A quasi-experimental study in late French immersion. The Modern Language Journal, 95(s1), 182-198.

Turnbull, M., Hart, D., \& Lapkin, S. (2003). Grade 6 French immersion students' performance on large-scale reading, writing, and mathematics tests: Building explanations. Alberta Journal of Educational Research, 49(1), 6-23.

Wall, A. (2010). Myths and realities of French immersion. Language Portal of Canada. Retrieved from http://205.193.86.57/collaborateurs-contributors/articles/mythesmyths-eng.html

Wenden, A. (1985). Learner strategies. Teachers of English to Speakers of Other Languages, 19(5), 1-7.

Willms, J. D. (2008). The case for universal French instruction. Policy Options, 29(7), 9196.

Wise, N. (2011). Access to special education for exceptional students in French immersion programs: An equity issue. Canadian Journal of Applied Linguistics/Revue canadienne de linguistique appliquée, 14(1), 177-193. 